\title{
BRAF NM_004333.4:C.1791A>G
}

National Cancer Institute

\section{Source}

National Cancer Institute. BRAFNM 004333.4:C.1791A>G. NCI Thesaurus. Code C98329.

A nucleotide substitution at position 1791 of the coding sequence of the BRAF gene

where adenine has been mutated to guanine. 